\title{
An Aspiration of Cocklebur (Xanthium strumarium) Showing Impaired Swallowing Reflex in a Patient with Chronic Obstructive Pulmonary Disease
}

\author{
KOAH'I Bir Hastada PItrak Tohumu (Xanthium strumarium) Aspirasyonu \\ Yutma Refleksinin Bozulduğunu Göstermektedir
}

Hikmet Çoban, Adil Can Güngen, Yusuf Aydemir, Hasan Düzenli, Cahit Bilgin, Canatan Taşdemir

\begin{abstract}
A 64-year-old male patient who was under follow-up for chronic obstructive pulmonary disease (COPD) for 10 years was admitted with persistent cough for the past two years. Bronchoscopy due to atelectasis of the right lower lobe showed aspiration of common cocklebur (Xanthium strumarium). Herein, we present the dramatic case of COPD with accidental aspiration of a foreign body with spiny projections, which was large for the respiratory system and resulted in impaired swallowing reflex.
\end{abstract}

Key words: COPD, swallowing reflex, common cocklebur.
Özet

Son iki yıldır geçmeyen öksürük şikâyeti olan kronik obstrultif akciğer hastalığı (KOAH) tanılı hastada, sağ alt zonda atelektazi izlenmesi üzerine yapılan bronkoskopide pıtrak tohumu (Xanthium strumarium) aspirasyonu tesbit edildi. Solunum sistemi için hacimce büyük, dikensi çıkıntıları olan bir yabancı cismi, hastanın farkında olmadan aspire etmesini, KOAH'lı hastalarda yutma refleksindeki bozulmayı gösteren, dramatik bir örnek olduğu için sunuyoruz.

Anahtar Sözcükler: KOAH, yutma refleksi, bıtrak tohumu.
Foreign body aspirations usually occur in children. In adults, it is often associated with impairment of the swallowing reflex in conditions such as mental retardation, neurological disorders, and loss of consciousness. It has been demonstrated that swallowing reflex is impaired in patients with chronic obstructive pulmonary disease (COPD), which may lead lo aspirations and exacerbations eventually. Herein, we present an interesting case of aspiration with COPD.

Sağlık Bakanlığı Sakarya Üniversitesi Tıp Fakültesi Eğitim ve Araştırma Hastanesi, Göğüs Hastalıkları Kliniği, Sakarya

Department of Chest Diseases, Ministry of Health Sakarya Univer-

sity Medical School Training and Research Hospital, Sakarya, Turkey

Submitted (Başvuru tarihi): 05.05.2016 Accepted (Kabul tarihi): 15.08 .2016

Correspondence (iletişim): Hikmet Çoban, Department of Chest Diseases, Ministry of Health Sakarya University Medical School Training and Research Hospital, Sakarya, Turkey

e-mail: hikmetcoban04@gmail.com 


\section{CASE}

A 64 -year-old male patient who was followed for COPD for 10 years presented with a complaint of severe cough persisting even during stable periods of his condition for the past two years. During follow-up, his complaint of cough was attributed to his present condition and he had an episode of hospitalization. Being an ex-smoker for five years, he had a 50 pack/year history of smoking with purulent sputum without hemoptysis. He had no comorbidities. Pulmonary function test showed a forced vital capacity (FVC) of $2500 \mathrm{~mL}(66 \%)$, a forced expiratory volume in 1 second (FEVI) of $1330 \mathrm{~mL}(46 \%)$, and a FEVI/FVC ratio of $46 \%$. Auscultation revealed diminished breath sounds with a prolonged expirium, and thin rales in the right base, while the results of other system examinations were normal. A chest $\mathrm{X}$-ray showed a homogeneous area in the right lower lobe (Figure 1). The diaphragm contour was elevated in the right side secondary to atelectasis. Blood count values were normal with a Creactive protein (CRP) level of $25.6 \mathrm{mg} / \mathrm{L}$. Thoracic CT showed a lesion blocking the right intermediate bronchus. Atelectasis and post-obstructive area of pneumonic consolidation were observed in the periphery of the lesion (Figures 2 and 3). Bronchoscopy showed an almost completely occluded right intermediate bronchus. The lesion included radial projections (Figure 4). The lesion was detached using forceps to avoid any complication relating to the foreign body. A plenty of purulent secretion was aspirated from the lesion. By retracting it toward the proximal from its current position, the body was re-grasped by forceps and removed by bronchoscopy. After removal of the lesion, it was found out that it was a cocklebur (Xanthium strumarium) (Figure 5). A complete recovery was achieved in post-obstructive pneumonia by oral antibiotic therapy. The evaluation of swallowing was performed by gag (pharyngeal reflex) reflex. The soft palate and posterior pharyngeal wall were stimulated and a decrease in the elevation and contraction of the pharyngeal muscles was observed. The test result was evaluated decreased gag reflex.

\section{DISCUSSION}

The swallowing reflex occurs in two dynamic and complex phases. At the time when a food is swallowed, there occurs a pause in breathing for a few seconds, and the breath returns in the expiratory phase, thereby avoiding aspiration (1). In cases where the relationship between breathing and swallowing reflex is disturbed, the risk of aspiration increases (2-4). Patients with COPD may de- velop abnormalities in swallowing reflex due to dyspnea and impaired thoraco-abdominal biomechanics, as these patients do not have the respiratory pause required in the normal swallowing process (5). The impaired swallowing leads to micro-aspiration, which may be a potential risk factor for COPD exacerbation (6).

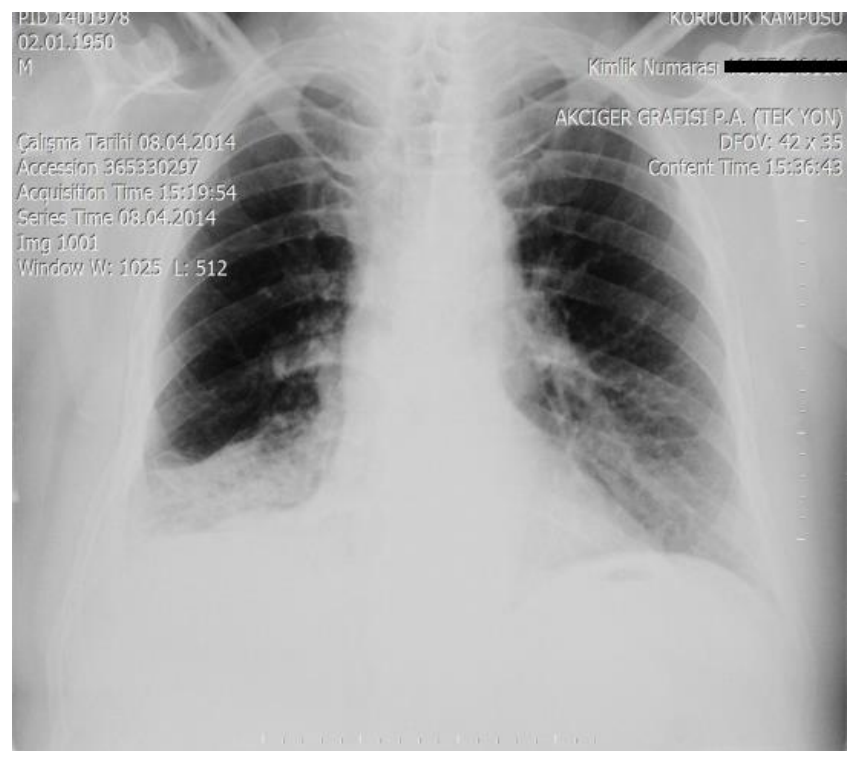

Figure 1: An increased density in the right lower lobe and impairment and deletion in the right diaphragm contour are observed

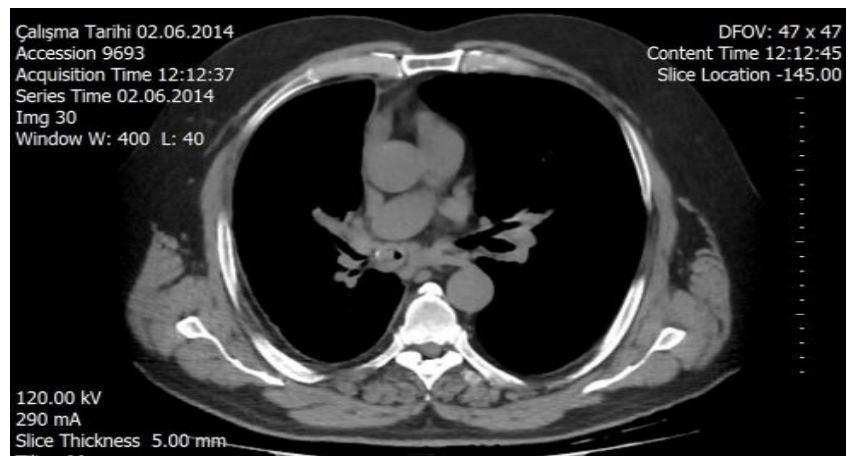

Figure 2: A lesion blocking the right intermediate bronchus is observed

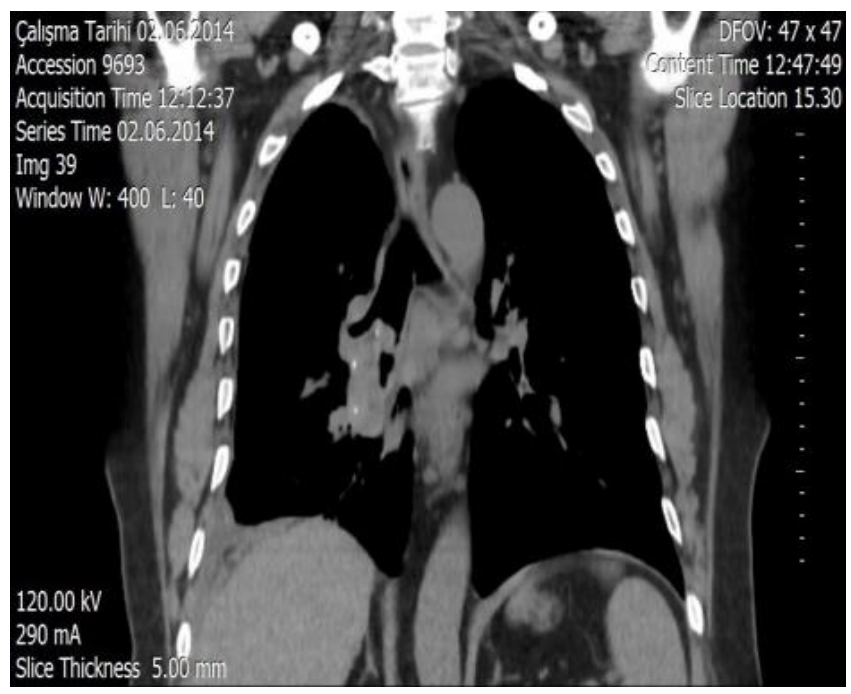

Figure 3: A lesion blocking the right intermediate bronchus is observed 


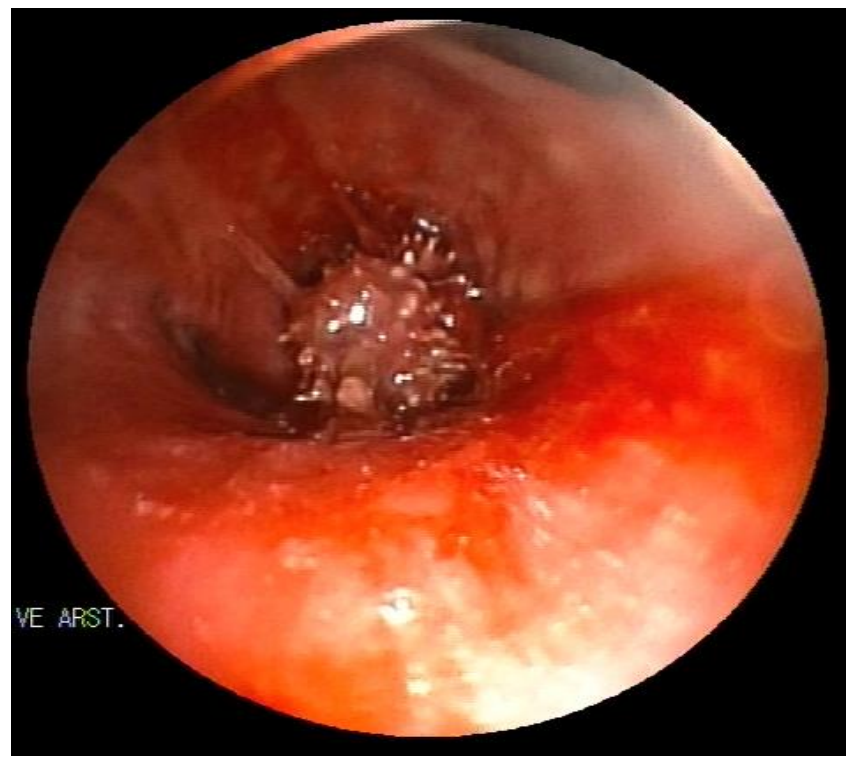

Figure 4: Location of the cocklebur seed in the intermediate bronchus and its appearance after removal by bronchoscopy

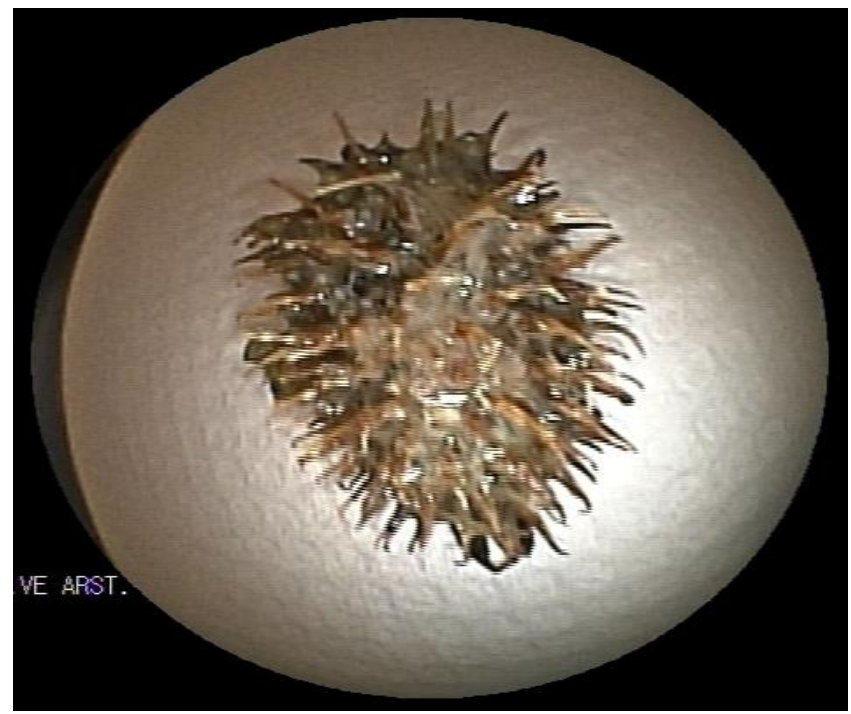

Figure 5: Location of the cocklebur seed in the intermediate bronchus and its appearance after removal by bronchoscopy

Although clinical evaluation showed normal swallowing, videofluoroscopic examination revealed that laryngotracheal aspiration reduced due to the decreased sensitivity of the laryngeal region (7).

Several studies assessing how swallowing dysfunction occurs in COPD have suggested that patients with COPD have a longer pharyngeal phase of swallowing (1). It is associated with a decrease in the difference between duration of maximal laryngeal elevation and duration of pharyngeal transit (8). Patients with COPD have significantly less mechano-sensitivity in the laryngopharynx, which contributes to an increased risk of aspiration (9). However, the aspiration of a foreign body does not mean that the patient has an impairment of swallowing reflex. Many patients have aspiration without any impairment.
The risk of aspiration in patients with COPD can be reduced by decreasing the sensitivity of the airways (7).

The seed of Xanthium Strumarium, commonly known as cocklebur, has been commonly used in herbal medicine. Its oil has been shown to have anti-inflammatory, antimicrobial, and scolicidal activity $(10,11)$. However, potentially fatal toxicities have been reported in animals and humans $(12,13)$. To the best of our knowledge, this is the first case report of its aspiration in the literature. In our case, medical history revealed that he swallowed cocklebur seeds two years ago, believing that it might relieve hemorrhoid-related complaints; however, he was unable to report any aspiration. We believe that accidental aspiration of a large volume foreign body with spiny projections is a dramatic example to show the extent of impairment in swallowing reflex in COPD.

In conclusion, impaired swallowing reflex is an underestimated condition in COPD patients. We believe that swallowing reflex should be tested and evaluated for aspiration in patients with frequent exacerbations and lack of clinical stability.

\section{CONFLICTS OF INTEREST}

None declared.

\section{AUTHOR CONTRIBUTIONS}

Concept - H.Ç., A.C.G., Y.A., H.D., C.B., C.T.; Planning and Design - H.Ç., A.C.G., Y.A., H.D., C.B., C.T.; Supervision - H.Ç., A.C.G., Y.A., H.D., C.B., C.T.; Funding - H.Ç., Y.A.; Materials - H.Ç., C.B.; Data Collection and/or Processing - H.Ç., C.T.; Analysis and/or Interpretation - H.Ç., Y.A.; Literature Review - H.Ç., H.D.; Writing - H.Ç., C.B., A.C.G.; Critical Review - A.C.G.

\section{YAZAR KATKILARI}

Fikir - H.Ç., A.C.G., Y.A., H.D., C.B., C.T.; Tasarım ve Dizayn - H.Ç., A.C.G., Y.A., H.D., C.B., C.T.; Denetleme - H.Ç., A.C.G., Y.A., H.D., C.B., C.T.; Kaynaklar - H.Ç., Y.A.; Malzemeler - H.Ç., C.B.; Veri Toplama ve/veya Issleme - H.Ç., C.T.; Analiz ve/veya Yorum - H.Ç., Y.A.; Literatür Taraması - H.Ç., H.D.; Yazıyı Yazan - H.Ç., C.B., A.C.G.; Eleştirel İnceleme - A.C.G.

\section{REFERENCES}

1. O'Kane L, Groher M. Dysphagia and obstructive pulmonary disease: a systematic review. Rev CEFAC 2009; $11: 499-506$.

2. Steidl E, Ribeiro CS, Gonçalves BF, Fernandes N, Antunes $V$, et al. Relationship between dysphagia and exac- 
erbations in chronic obstructive pulmonary disease: a literature review. Int Arch Otorhinolaryngol 2015; 19:74-9. [CrossRef]

3. Chaves Rde D, Carvalho CR, Cukier A, Stelmach R, Andrade CR. Symptoms of dysphagia in patients with COPD. J Bras Pneumol 2011 ; 37:176-83.

4. Mokhlesi B, Logemann JA, Rademaker AW, Stangl CA, Corbridge TC. Oropharyngeal deglutition in stable COPD. Chest 2002; 121:361-9. [CrossRef]

5. Singh B. Impaired swallow in COPD. Respirology 2011 ; 16:185-6. [CrossRef]

6. Kobayashi S, Kubo H, Yanai M. Impairment of the swallowing reflex in exacerbations of COPD. Thorax. 2007; 62:1017. [CrossRef]

7. Bastilha GR, Rocha RM, Gonçalves BFT, Bilheri DFD. Results of clinical evaluation and objective of swallowing in patients with chronic cough: case report. Int Arch Otorhinolaryngol 2012; 16(Suppl 01):98. [CrossRef]

8. Cassiani RA, Santos CM, Baddini-Martinez J, Dantas RO Oral and pharyngeal bolus transit in patients with chronic obstructive pulmonary disease. Int J Chron Obstruct Pulmon Dis. 2015; 10:489-96. [CrossRef]
9. Clayton NA, Carnaby-Mann GD, Peters MJ, Ing AJ. The effect of chronic obstructive pulmonary disease on laryngopharyngeal sensitivity. Ear Nose Throat J 2012; 91:370-4.

10. Khuda F, lqbal Z, Khan A, Zakiullah, Shah Y, Ahmad L, et al. Evaluation of anti-inflammatory activity of selected medicinal plants of Khyber Pakhtunkhwa, Pakistan. Pak J Pharm Sci. 2014; 27:365-8.

11. Sharifi-Rad J, Hoseini-Alfatemi SM, Sharifi-Rad M, Sharifi-Rad $M$, Iriti $M$, et al. Phytochemical compositions and biological activities of essential oil from Xanthium strumarium L. Molecules 2015; 20:7034-47. [CrossRef]

12. Botha CJ, Lessing $D$, Rösemann $M$, van Wilpe $E$, Williams $\mathrm{JH}$. Analytical confirmation of Xanthium strumarium poisoning in cattle. J Vet Diagn Invest 2014; 26:640-5. [CrossRef]

13. Karabiber $H$, Almis $H$, Selimoglu MA, Yakinci $C$, Yilmaz $S$. Xanthium strumarium poisoning requiring liver transplantation. J Pediatr Gastroenterol Nutr 2014; 58:e6-9. [CrossRef] 